\title{
EXAMINATION OF THE EFFECT OF COMORBID DISEASES AND VITAMIN LEVELS ON SLEEP QUALITY
}

\section{KOMORBİD HASTALIKLARIN VE VITTAMINN DÜZEYLERİNIN UYKU KALITTESİNE ETKİSININ İNCELENMESI}

Murat YILMAZ ${ }^{1}$, İrem Deniz KARAKAYA', Şule AYDIN TURKOGLU ${ }^{1}$, Serpil YILDIZ ${ }^{1}$

\section{ABSTRACT}

AIM: The aim of this study was to investigate the relationship between comorbid diseases, vitamins levels and sleep quality of patients undergoing polysomnography (PSG) in a sleep clinic.

MATERIAL AND METHOD: Fifty-two patients who underwent PSG between January 2018 and December 2018 at Bolu Abant İzzet Baysal Training and Research Hospital Sleep Clinic were included in the study. PSG measurements were performed in the sleep clinic following appropriate preparatory procedures.

RESULTS: Of the study group, 41 (78.8\%) were male and 11 $(21.2 \%)$ were female. The mean age was $49.25 \pm 12.77$ years. The number of sleep apneas $(\mathrm{p}=0.013)$, central apnea $(\mathrm{p}=0.037)$, apnea / hypopnea index $(\mathrm{p}=0.026)$ and RDI $(\mathrm{p}=0.021)$ were higher in patients with diabetes mellitus (DM). It was found that REM sleep time was shortened in patients with hypertension $(\mathrm{HT})(\mathrm{p}=0.021)$ and patients with CAD $(\mathrm{p}=0.013)$. There was a positive weak correlation between vitamin $\mathrm{D}$ levels and stage 2 sleep duration $(\mathrm{p}=0.032, \mathrm{r}=0.309)$. As folate levels $(\mathrm{p}=0.039, \mathrm{r}=-0.305)$ and vitamin B12 levels $(\mathrm{p}=0.035, \mathrm{r}=-0.305)$ increased, arousal index values decreased.

CONCLUSION: HT and CAD have very limited effects on sleep. In addition, DM most negatively affected sleep parameters in this study. It was also found that the evaluated vitamin levels affect sleep only very limited in some parameters.

Keywords: comorbidity, polysomnography, vitamin levels

\section{ÖZET}

AMAÇ: Bu çalışmanın amacı, bir uyku kliniğinde polisomnografi (PSG) yapılan hastaların komorbid hastalıkları, vitamin düzeyleri ve uyku kalitesi arasındaki ilişkiyi araştırmaktır.

GEREÇ VE YÖNTEM: Bolu Abant İzzet Baysal Eğitim ve Arastırma Hastanesi Uyku Kliniği'nde Ocak 2018-Aralık 2018 tarihleri arasında PSG uygulanan 52 hasta çalışmaya dahil edildi. PSG ölçümleri uygun hazırlı prosedürlerini takiben uyku kliniğinde yapıldı.

BULGULAR: Çalışma grubunun 41'i $(\% 78,8)$ erkek, 11'i $(\% 21,2)$ kadındı. Ortalama yaş $49.25 \pm 12.77$ idi. Uyku apnesi sayısı $(\mathrm{p}=0.013)$, santral apne $(\mathrm{p}=0.037)$, apne / hipopne indeksi $(\mathrm{p}=$ $0.026)$ ve RDI ( $p=0.021)$ diabetes melllitus $(\mathrm{DM})$ hastalarında daha yüksekti. Hipertansiyonlu (HT) hastalarda $(\mathrm{p}=0.021)$ ve koroner arter hastalığ $1(\mathrm{KAH})$ olanlarda $(\mathrm{p}=0.013)$ REM uyku süresinin kısaldığı tespit edildi. D vitamini düzeyleri ile 2. evre uyku süresi arasında pozitif yönde zayıf korelasyon vardı $(\mathrm{p}=0.032, \mathrm{r}=0.309)$. Folat seviyeleri $(\mathrm{p}=0.039, \mathrm{r}=-0.305)$ ve $\mathrm{B} 12$ vitamini seviyeleri $(\mathrm{p}=0.035, \mathrm{r}=-0.305)$ arttıkça arousal indeks değerleri azaldı.

SONUÇ: HT ve KAH uyku üzerinde çok sınırlı etkiye sahiptir. Ek olarak, bu çalışmada uyku parametrelerini en fazla DM olumsuz olarak etkilemiştir. Değerlendirilen vitamin düzeylerinin de uykuyu bazı parametrelerde çok sınırlı düzeyde etkilediği bulunmuştur.

Anahtar Kelimeler: komorbidite, polisomnografi, vitamin düzeyleri

${ }^{1}$ Department of Neurology, Bolu Izzet Baysal University, Bolu, Turkey

Geliş Tarihi / Submitted : Şubat 2021 / February 2021

Kabul Tarihi / Accepted : Aralık 2021 / December 2021

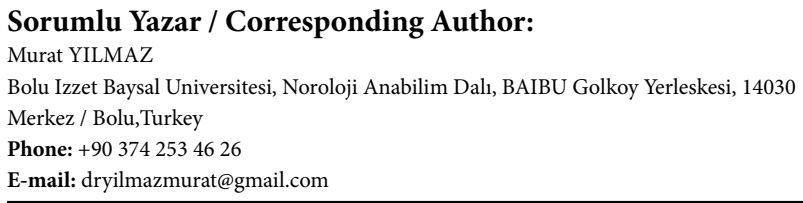

Yazar Bilgileri /Author Information:

Murat YILMAZ (ORCID: 0000-0002-5308-4653),

Irem Deniz KARAKAYA (ORCID: 0000-0003-4053-8051) E-mail: iremdenizatasoy@gmail.com, Sule Aydin TURKOGLU (ORCID : 0000-0001-8616-832X)

E-mail: suleaydinturkoglu@hotmail.com,

Serpil YILDIZ (ORCID : 0000-0002-9647-4432) E-mail: serpilkuyucu@hotmail.com 


\section{INTRODUCTION}

Good sleep quality is a well-known indicator of general liveliness as both physical and mental health. General satisfaction with sleep experience requires both an optimal time and good sleep quality. Therefore, sleep of poor quality can be described as insufficient sleep (shortterm) or sleep of low quality or the presence of both in the general terms.(1)

There can be several parameters that affect sleep quality. In recent years, increasing attention has been paid to a possible connection between significant comorbidities including glucose metabolism disorders such as diabetes mellitus (DM) and hypertension (HT), and coronary artery disease (CAD).(2-5) In previous studies, it was stated that poor sleep is a common characteristic of type 2 diabetes, and these patients have difficulty in initiating and maintaining sleep, daytime sleep and low sleep quality.(6-8) Similarly, there are also studies reporting a positive correlation between hypertension and poor sleep quality.(9-11) Sleep has an important role in the modulation of heart rate and blood pressure and protection of cardiovascular homeostasis. The role of sleep in balancing the blood pressure is based on the reduction of catecholamine secretion. $(12,13)$ It is known that there is a correlation between sleep disorders, tachycardia and hypertension, and this negatively affects the cardiovascular system.(14, 15) Moreover, a correlation has also been demonstrated between obstructive sleep apnea, which is a sleep disorder, and cardiovascular mortality.(16)

There are also studies stating a correlation between the biochemical parameters such as vitamin deficiencies, in addition to the aforementioned chronic diseases, and sleep quality. Clinical studies conducted especially on humans show that low vitamin D levels are correlated with low quality and short sleep time.(17) Besides, in another study, vitamin D levels and sleep were evaluated, and consequently, a statistically significant correlation was found between short sleep hours ( $<7$ hours of sleep), sleeping problem, sleep disorder and low sleep quality and low vitamin $\mathrm{D}$ levels. In the same study, a correlation was reported between vitamin B12 and insomnia as well.(18) Although there are studies pointing at a correlation between vitamins and sleep quality, no sufficient information is available about which mechanisms they affect sleep quality with. Additionally, in most studies, sleep quality was evaluated with subjective survey methods. $(2,5,11)$ In this field, studies based on the evaluation of the correlation between sleep quality and mental disorders with objective methods such as polysomnography are encountered, however, there are few studies measuring the effect of comorbid diseases and vitamin levels on sleep quality.(19)

In this study, it was aimed to research the correlation between comorbid diseases and some vitamin levels and sleep quality in patients whose sleep evaluation was made via polysomnography.

\section{MATERIAL AND METHOD}

A total of 52 patients who underwent polysomnography
(PSG) in the Sleep Clinic of $x x x x x x x x x x x x$ between January 2018 and December 2018 were included in the study.

Necessary permissions were obtained from the Clinical

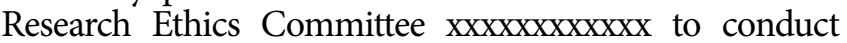
the study. (Approval number: 1012016904, Approval date: 12/09/2019) and all the patients were informed about the study and their written informed consents were obtained. Those with a neurological disease other than sleep complaints, patients whose PSG measurements were not carried out properly, and patients who were taking medication that might change the sleep structure were excluded from the study. Whether the patients had diabetes mellitus (DM), hypertension (HT) and coronary heart disease (CAD), their vitamin $\mathrm{D}, \mathrm{B} 12$, folate levels, TSH, T3, T4 levels, hemogram measurements and cholesterol measurements were recorded.

\section{PSG Measurements}

PSG measurement was executed in line with the guidelines of the American Academy of Sleep Medicine in the Sleep Clinic of Bolu Abant İzzet Baysal Training and Research Hospital (20). Lights were turned off at 22.00 at night and turned on at 07.00 in the morning. Throughout the night, PSG (Polysomnography system Natus Embla brand N7000 model) recording was active.

PSG record included the following parameters: electroencephalogram (according to the international 10-20 system: F3, F4, C3, C4, P3, P4, O1, 02, [grounding to $\mathrm{AFz}$ and reference electrode in $\mathrm{FCz}$ position); right and left electrooculogram; submental and both anterior tibialis muscles; body position; electrocardiogram (ECG); thoracic and abdominal piezoelectric transducers; oronasal air flow (thermistor); and oxygen saturation.

As a result of PSG measurement, patients' total sleep times, stage 1, 2, 3 NREM sleep times, REM sleep times, sleep latency, REM latency, sleep efficiency, mixed, central apnea numbers, apnea/hypopnea index, and aurosol index values were recorded.

\section{Statistical Analysis}

Study data were analyzed after being transferred to SPSS (v20) software. Categorical variables were stated in frequency (percentage), and continuous variables were expressed as mean \pm standard deviation or median (interquartile range $=$ IR) according to the normal distribution. In the comparison of continuous variables, the independent samplest test and Mann-Whitney U test were used according to the normality. Categorical variables were assessed via the Chi-Square test or Fisher's exact test. Pearson or Spearman correlation test was used for the correlation analysis of the continuous variables according to the normality. $\mathrm{p}<0.05$ was accepted for statistical significance.

\section{RESULTS}

In the study group, 41 (78.8\%) individuals were male, 11 $(21.2 \%)$ were female; the mean age was $49.25 \pm 12.77$. The 
median (IR) number of apneas observed in one hour during sleep was 26 (8.5-100). The median (IR) apnea/ hypopnea index was 21.5 (7.7-44.5). Main characteristics of the study group are shown in Table 1.

No significant difference was detected between women and men in terms of the PSG result. When the correlation between age and PSG parameters was checked, a positive, weak correlation was discovered between age and central apnea number $(\mathrm{p}=0.041, \mathrm{r}=0.290)$ and respiratory distress index (RDI) ( $p=0.045, r=0.290)$. It was observed that the number of apneas observed in one hour during sleep $(\mathrm{p}=0.013)$, central apnea number $(\mathrm{p}=0.037)$, apnea/ hypopnea index $(\mathrm{p}=0.026)$ and $\operatorname{RDI}(\mathrm{p}=0.021)$ were higher in those with DM than the ones without it. REM sleep times of the HT patients $(p=0.021)$ and patients with coronary artery disease $(\mathrm{p}=0.013)$ were found to get shorter (Table 2).

A positive, weak correlation was observed between vitamin D levels and stage 2 sleep time $(\mathrm{p}=0.032, \mathrm{r}=0.309)$. As the folate levels $(\mathrm{p}=0.039, \mathrm{r}=-0.305)$ and vitamin B12 levels $(p=0.035, r=-0.305)$ increased, arousal index values decreased. As PTH levels increased, stage 2 sleep times increased $(\mathrm{p}=0.032, r=0.301)$, stage 3 sleep times $(\mathrm{p}=0.036, \mathrm{r}=-0.294)$ and arousal index values $(\mathrm{p}=0.035, \mathrm{r}=$ $-0.293)$ decreased. While a negative, weak correlation was found between uric acid and REM latency $(\mathrm{p}=0.041, \mathrm{r}=$ -0.299), a positive, weak correlation was observed between magnesium values and sleep efficiency $(\mathrm{p}=0.040, \mathrm{r}=0.292)$.

\section{DISCUSSION}

Sleep quality is emphasized as an important concept due to its relationship with numerous physical, mental and sleep disorders.(21) Changes in the sleep structure throughout the night are independently correlated with quality of life, cognitive function, physical performance and even survival.(22) Sleep time and distribution of the stages of night's sleep can be affected negatively by various chronic diseases or medication used for these diseases.(23) In this study, it was aimed to make an evaluation on sleep in patients with DM, HT and CAD via PSG, which enables objective observation of sleep, and to assess the correlation between sleep and some biochemical parameters.

In the study, the number of apneas observed in one hour during sleep, central apnea number, apnea/hypopnea index and RDI were found to be higher in patients with DM. In a recent comprehensive systematic review evaluating the results of 16 cohort studies, it was shown that there is a significant two-way linear relationship between type 2 DM and obstructive sleep apnea.(24) In another review, it was emphasized that there is a linear relationship between $\mathrm{DM}$ and deterioration of sleep parameters.(25) In previous studies, DM was also associated with many chronic diseases such as obstructive sleep apnea, cardiovascular complications, hypertension, cerebrovascular events and depression, which may disturb sleep and quality of life in addition to directly causing sleep disorders as a result of nocturia, polyuria, diabetic neuropathy and neuropathic pain. $(26,27)$

Table 1. Main characteristics of the study group

\begin{tabular}{l|l} 
Gender, n (\%) & Values \\
Male & $41(78.8 \%)$ \\
Female & $11(21.2 \%)$ \\
Age, Mean \pm SD & $49.2 \pm 12.7$ \\
having DM, n (\%) & $11(21.2 \%)$ \\
having HT, $(\%)$ & $16(30.8 \%)$ \\
having CAD, n (\%) & $8(15.4 \%)$ \\
Total sleep time (Min), median (IR) & $408(364-432)$ \\
Stage 1 (Min), median (IR) & $9.3(4.7-14.5)$ \\
Stage 2 (Min), median (IR) & $64.1(58.3-69.5)$ \\
Stage 3 (Min), median (IR) & $12.8(8.9-18.2)$ \\
REM (\%), median (IR) & $10.9(8.1-13.8)$ \\
Sleep latency (Min), median (IR) & $4.2(1.1-10.3)$ \\
REM latency (Min), median (IR) & $118.5(94.0-249.5)$ \\
Sleep efficiency (\%), median (IR) & $94(87-97)$ \\
Obstructive apnea, median (IR) & $26(8.5-100)$ \\
Mixed apnea, median (IR) & $1(0-8.2)$ \\
Central apnea, median (IR) & $1(0-3)$ \\
Hypopnea, median (IR) & $90.5(31.5-151.2)$ \\
Apnea+hypopnea, median (IR) & $151.5(51.2-293.7)$ \\
A/H index, median (IR) & $21.5(7.7-44.5)$ \\
RDI, median (IR) & $21.5(8.0-43.7)$ \\
\hline
\end{tabular}

Mean \pm SD: Mean \pm Standard Deviation,

Min: Minute

DM: Diabetes Mellitus,

HT: Hypertension,

CAD: Coronary artery disease,

IR: Interquartile range,

A/H index: Apnea/Hypopnea index,

RDI: Respiratory distress index 
Table 2. Correlation between comorbid diseases and sleep parameters

\begin{tabular}{|c|c|c|c|c|c|c|c|c|c|}
\hline \multirow[b]{3}{*}{$\begin{array}{l}\text { Total sleep } \\
\text { time (Min) }\end{array}$} & \multicolumn{2}{|c|}{ DM } & \multirow[t]{2}{*}{$\mathbf{p}$} & \multicolumn{2}{|c|}{ HT } & \multirow[t]{2}{*}{$\mathbf{p}$} & \multicolumn{2}{|c|}{ CAD } & \multirow[t]{2}{*}{$\mathbf{p}$} \\
\hline & Yes & No & & Yes & No & & Yes & No & \\
\hline & $\begin{array}{c}413 \\
(219-463)\end{array}$ & $\begin{array}{c}408 \\
(371-431)\end{array}$ & 0.936 & $\begin{array}{c}402 \\
(265-443)\end{array}$ & $\begin{array}{c}409 \\
(380-432)\end{array}$ & 0.417 & $\begin{array}{c}380 \\
(242-416)\end{array}$ & $\begin{array}{c}409 \\
(369-433)\end{array}$ & 0.195 \\
\hline Stage 1 (Min) & $\begin{array}{c}10.7 \\
(2.3-24.6)\end{array}$ & $\begin{array}{c}9.3 \\
(5.0-13.5)\end{array}$ & 0.946 & $\begin{array}{c}12.0 \\
(4.7-22.7)\end{array}$ & $\begin{array}{c}8.4 \\
(4.6-12.4)\end{array}$ & 0.226 & $\begin{array}{c}10.9 \\
(6.2-50.3)\end{array}$ & $\begin{array}{c}9.0 \\
(4.5-14.3)\end{array}$ & 0.518 \\
\hline Stage 2 (Min) & $\begin{array}{c}63.8 \\
(48.9-72.7)\end{array}$ & $\begin{array}{c}64.2 \\
(58.9-68.8)\end{array}$ & 0.840 & $\begin{array}{c}64.3 \\
(51.1-72.1)\end{array}$ & $\begin{array}{c}63.9 \\
(58.8-66.9)\end{array}$ & 0.751 & $\begin{array}{c}64.3 \\
(43.9-70.5)\end{array}$ & $\begin{array}{c}63 \\
(58-69)\end{array}$ & 0.780 \\
\hline Stage 3 (Min) & $\begin{array}{c}7.8 \\
(7.4-15.3)\end{array}$ & $\begin{array}{c}12.8 \\
(10.0-18.3)\end{array}$ & 0.198 & $\begin{array}{c}11.5 \\
(7.5-17.1)\end{array}$ & $\begin{array}{c}12.8 \\
(9.9-19.2)\end{array}$ & 0.197 & $\begin{array}{c}8.5 \\
(6.9-21.4)\end{array}$ & $\begin{array}{c}12.9 \\
(9.9-18.2)\end{array}$ & 0.171 \\
\hline REM (\%) & $\begin{array}{c}10.0 \\
(2.2-11.5)\end{array}$ & $\begin{array}{c}11.5 \\
(8.1-14.4)\end{array}$ & 0.172 & $\begin{array}{c}8.7 \\
(4.3-11.3)\end{array}$ & $\begin{array}{c}12 \\
(8.2-15.5)\end{array}$ & 0.021 & $\begin{array}{c}6.5 \\
(1.7-11.1)\end{array}$ & $\begin{array}{c}11.3 \\
(8.2-14.6)\end{array}$ & 0.015 \\
\hline $\begin{array}{l}\text { Sleep latency } \\
\text { (Min) }\end{array}$ & $\begin{array}{c}3.0 \\
(0.5-5.5)\end{array}$ & $\begin{array}{c}5.0 \\
(1.5-11.2)\end{array}$ & 0.205 & $\begin{array}{c}3.0 \\
(0.5-12.1)\end{array}$ & $\begin{array}{c}5.0 \\
(1.5-10.3)\end{array}$ & 0.606 & $\begin{array}{c}4.0 \\
(0.8-25.8)\end{array}$ & $\begin{array}{c}4.2 \\
(1.1-10.0)\end{array}$ & 0.637 \\
\hline $\begin{array}{l}\text { REM latency } \\
\text { (Min) }\end{array}$ & $\begin{array}{c}108 \\
(80-320)\end{array}$ & $\begin{array}{c}119 \\
(95-247)\end{array}$ & 0.893 & $\begin{array}{c}117 \\
(88-219)\end{array}$ & $\begin{array}{c}126 \\
(94-255)\end{array}$ & 0.670 & $\begin{array}{c}90 \\
(78-144)\end{array}$ & $\begin{array}{c}141 \\
(100-255)\end{array}$ & 0.100 \\
\hline $\begin{array}{l}\text { Sleep efficiency } \\
(\%)\end{array}$ & $\begin{array}{c}91 \\
(82-98)\end{array}$ & $\begin{array}{c}94 \\
(87-96)\end{array}$ & 0.927 & $\begin{array}{c}89 \\
(70-96)\end{array}$ & $\begin{array}{c}95 \\
(90-97)\end{array}$ & 0.108 & $\begin{array}{c}90 \\
(61-98)\end{array}$ & $\begin{array}{c}94 \\
(88-97)\end{array}$ & 0.726 \\
\hline $\begin{array}{l}\text { Obstructive } \\
\text { sleep apnea }\end{array}$ & $\begin{array}{c}3 \\
(2-3)\end{array}$ & $\begin{array}{c}1.5 \\
(1.0-3.0)\end{array}$ & 0.013 & $\begin{array}{c}2 \\
(1-3)\end{array}$ & $\begin{array}{c}2 \\
(1-3)\end{array}$ & 0.234 & $\begin{array}{c}3.0 \\
(1.2-3.09)\end{array}$ & $\begin{array}{c}2 \\
(1-3)\end{array}$ & 0.122 \\
\hline Mixed apnea & $\begin{array}{c}8 \\
(0-10)\end{array}$ & $\begin{array}{c}0 \\
(0-3)\end{array}$ & 0.167 & $\begin{array}{c}1.5 \\
(0-9.5)\end{array}$ & $\begin{array}{c}0 \\
(0-6.7)\end{array}$ & 0.450 & $\begin{array}{c}5 \\
(0-9.7)\end{array}$ & $\begin{array}{c}1.0 \\
(0-4.5)\end{array}$ & 0.495 \\
\hline Central apnea & $\begin{array}{c}2 \\
(1-6)\end{array}$ & $\begin{array}{c}1 \\
(0-2)\end{array}$ & 0.037 & $\begin{array}{c}1.5 \\
(1.0-5.2)\end{array}$ & $\begin{array}{c}1 \\
(0-2.2)\end{array}$ & 0.201 & $\begin{array}{c}1.5 \\
(0-5.2)\end{array}$ & $\begin{array}{c}1.0 \\
(0-2.2)\end{array}$ & 0.733 \\
\hline Hypopnea & $\begin{array}{c}128 \\
(81-283)\end{array}$ & $\begin{array}{c}57 \\
(23-147)\end{array}$ & 0.064 & $\begin{array}{c}119 \\
(40-176)\end{array}$ & $\begin{array}{c}82 \\
(19-151)\end{array}$ & 0.303 & $\begin{array}{c}134 \\
(37-185)\end{array}$ & $\begin{array}{c}82 \\
(26-151)\end{array}$ & 0.467 \\
\hline $\begin{array}{l}\text { Apnea } \\
+ \text { hypopnea }\end{array}$ & $\begin{array}{c}230 \\
(127-373)\end{array}$ & $\begin{array}{c}112 \\
(46-215)\end{array}$ & 0.069 & $\begin{array}{c}146 \\
(68-281)\end{array}$ & $\begin{array}{c}159 \\
(34-294)\end{array}$ & 0.519 & $\begin{array}{c}201 \\
(74-339)\end{array}$ & $\begin{array}{c}131 \\
(51-277)\end{array}$ & 0.397 \\
\hline $\mathrm{A} / \mathrm{H}$ index & $\begin{array}{c}43 \\
(16-57)\end{array}$ & $\begin{array}{c}18 \\
(6-40)\end{array}$ & 0.026 & $\begin{array}{c}22 \\
(11-46)\end{array}$ & $\begin{array}{c}21 \\
(6-44)\end{array}$ & 0.270 & $\begin{array}{c}40 \\
(13-53)\end{array}$ & $\begin{array}{c}18 \\
(6-43)\end{array}$ & 0.164 \\
\hline RDI & $\begin{array}{c}43 \\
(16-57)\end{array}$ & $\begin{array}{c}18 \\
(6.5-18.5)\end{array}$ & 0.021 & $\begin{array}{c}22 \\
(11-46)\end{array}$ & $\begin{array}{c}21 \\
(6-43)\end{array}$ & 0.251 & $\begin{array}{c}40 \\
(13-53)\end{array}$ & $\begin{array}{c}18 \\
(7-41)\end{array}$ & 0.150 \\
\hline
\end{tabular}

Sleep parameters are stated as Median (Interquartile Range $=$ IR).

DM: Diabetes Mellitus

HT: Hypertension

CAD: Coronary artery disease

A/H index: Apnea/Hypopnea index

RDI: Respiratory distress index

In this study, DM was observed to be the disease, among the evaluated comorbid diseases, which influenced the sleep parameters the most negatively.

It is known that patients with hypertension are more sensitive to various cardiovascular diseases including stroke and coronary heart diseases.(28) Sufficient sleep time not only maintains the body function but also prevents negative cardiovascular results. For example, insufficient sleep has been associated with deaths resulting from hypertension and cardiovascular diseases. $(29,30)$ As a result of the study, it was found that only the REM period was affected among the sleep parameters in patients with $\mathrm{HT}$ and CAD, and the REM time gets shorter in these patients. In many studies, low sleep quality is indicated in patients with $\mathrm{HT}$ and CAD. Even though these results are similar to our study, sleep quality was assessed via the subjective survey method in most of these studies. $(31,32)$ In a study that investigated the correlation between blood pressure and sleep via PSG, no significant correlation could be revealed between the REM sleep and blood pressure. Besides, in the same study, it was reported that blood pressure fluctuations at night and in the morning were influenced by sleep disorders. (33) In a very recent systematic compilation study, where coronary heart diseases and sleep disorders have been evaluated, it has been put forward that both sleep amount and sleep quality are negatively affected in coronary events. Furthermore, it has been stated that sleep disorder becomes severer as the severity of ischemic events increases.(34) As a result, a correlation has been demonstrated between sleep disorders, which are evaluated with both subjective and objective methods, and HT and CAD. However, in the study, these diseases have negatively affected some of the PSG parameters. Since a lot of studies, including ours, are cross-sectional, the correlation between comorbid diseases and sleep quality cannot be evaluated clearly. 
In previous studies, sleep disorders were reported to be encountered more frequently in the deficiency of some vitamins and minerals, as in chronic diseases. For instance, a low vitamin D level was revealed to be associated with short sleep time, which was measured both subjectively and objectively. $(35,36)$ In a recent study, it has been shown that vitamin $\mathrm{D}$ level improves sleep duration and sleep quality.(37) In the study, stage 2 sleep time was found to decrease as the vitamin D level decreased.

As in vitamin $\mathrm{D}$, deficiency of B-group vitamins and minerals may disrupt sleep. Their effect on sleep are said to be based on their effects on melatonin release.(38) Vitamin B12 contributes to melatonin release. In studies, it was reported as a result of treatment with vitamin B12 at varying doses that it had a potentially useful effect on circadian rhythm sleep disorder and delayed sleep phase type sleep disorder measured with actigraphy in healthy subjects while it was also mentioned that evidence was insufficient regarding a correlation with short sleep time. (38-40) In the study, the number of arousals, which are described as the sudden transitions to the more superficial sleep stage or state of wakefulness during the sleep, decreased whereas the vitamin B12 and folate levels increased. As a result of the effect of vitamin and mineral levels on serotonin and melatonin hormones, sleep may be influenced negatively. Consequently, some vitamin and mineral levels evaluated in the study in compliance with the literature had negative effects on sleep, however, these effects were found to be quite limited.

In the study, the objective evaluation of sleep via PSG had advantages but also some limitations. Even though the PSG evaluation was made according to the routine sleep times of the participants, the interpretation of sleep with single-night PSG records, and the problems arising from possible weak adaptation or lack of habits during the study may have affected the results. In addition, due to the nature of the cross-sectional study, we could not present a causal correlation between the evaluated chronic diseases, vitamin and mineral levels and the status of sleep. Lastly, the relatively low number of sample size is other limitation. Due to difficulties to find the patients undergone to PSG is the one of the reasons for this problem. The results and interpretations should be read by the awareness on these limitations.

\section{CONCLUSION}

As a result, HT and CAD had very limited effects on sleep in the study, however, DM was found to be the chronic disease which affected the sleep parameters the most negatively. Moreover, vitamin D, B12, PTH, folate, uric acid and magnesium levels were revealed to influence the sleep parameters. Considering that sleep disorders are observed more increasingly and correlated with some of the common chronic diseases in the world, the need for prospective studies and implementation of therapeutic strategies becomes clear in order to better reveal the correlation in this matter.
Acknowledgement: None.

Conflict of Interest: None. No competing financial interests exist.

\section{Authorship Contributions:}

Concept - M.Y.; Design - M.Y., S.B.A.; Supervision - S.Y; Materials - I.D.K, Data collection \&/or processing - M.Y., I.D.K.; Analysis and/or interpretation - M.Y.,S.A.T.; Literature search - M.Y, S.A.T; Writing-M.Y.; Critical review-S.A.T., S.K.

This research received no specific grant from any funding agency.

\section{REFERENCES}

1.) Ohayon M, Wickwire EM, Hirshkowitz M, et al. National Sleep Foundation's sleep quality recommendations: first report. Sleep Health. 2017; 3: 6-19.

2.) Akman $T$, Yavuzsen $T$, Sevgen $Z$, et al. Evaluation of sleep disorders in cancer patients based on Pittsburgh Sleep Quality Index. Eur J Cancer Care. 2015; 24: 553-9.

3.) Garcia S, Alosco ML, Spitznagel MB, et al. Poor sleep quality and reduced cognitive function in persons with heart failure. Int J Cardiol. 2012; 156: 248-9.

4.) Punjabi NM, Shahar E, Redline S, et al. Sleep-disordered breathing, glucose intolerance, and insulin resistance: the Sleep Heart Health Study. Am J Epidemiol. 2004; 160: 521-30.

5.) Liu R-Q, Qian Z, Trevathan E, et al. Poor sleep quality associated with high risk of hypertension and elevated blood pressure in China: results from a large population-based study. Hypertens Res. 2016; 39: 54-9.

6.) Knutson KL, Ryden AM, Mander BA, et al. Role of sleep duration and quality in the risk and severity of type 2 diabetes mellitus. Arch Intern Med. 2006; 166: 1768-74.

7.) Lamond N, Tiggemann M, Dawson D. Factors predicting sleep disruption in Type II diabetes. Sleep. 2000; 23: 415-6.

8.) Lopes LA, De Mm Lins C, Adeodato VG, et al. Restless legs syndrome and quality of sleep in type 2 diabetes. Diabetes Care. 2005; 28: 2633-6. 9.) Gangwisch JE. A review of evidence for the link between sleep duration and hypertension. Am J Hypertens. 2014; 27: 1235-42.

10.) Mohsenin V. Obstructive sleep apnea and hypertension: a critical review. Curr Hypertens Rep. 2014; 16: 482-4.

11.) Sforza E, Saint Martin M, Barthelemy JC, et al. Association of self-reported sleep and hypertension in non-insomniac elderly subjects. J Clin Sleep Med. 2014; 10: 965-71.

12.) Portaluppi F, Vergnani L, Manfredini R, et al. Endocrine mechanisms of blood pressure rhythms. Ann N Y Acad Sci. 1996; 783: 113-31.

13.) Bonsignore $M$, Marrone $O$, Insalaco $G$, et al. The cardiovascular effects of obstructive sleep apnoeas: analysis of pathogenic mechanisms. Eur Respir J. 1994; 7: 786-805.

14.) Mullington JM, Haack $M$, Toth $M$, et al. Cardiovascular, inflammatory, and metabolic consequences of sleep deprivation. Prog Cardiovasc Dis. 2009; 51: 294-302.

15.) Burgess HJ, Trinder J, Kim Y, et al. Sleep and circadian influences on cardiac autonomic nervous system activity. Am J Physiol Heart Circ Physiol. 1997; 273: H1761-H8.

16.) Marin JM, Carrizo SJ, Vicente E, et al. Long-term cardiovascular outcomes in men with obstructive sleep apnoea-hypopnoea with or without treatment with continuous positive airway pressure: an observational study. The Lancet. 2005; 365: 1046-53.

17.) Muscogiuri $G$, Barrea $L$, Scannapieco $M$, et al. The lullaby of the sun: the role of vitamin D in sleep disturbance. Sleep Med. 2019; 54: 262-5 
18.) Ikonte C, Reider C, Fulgoni Iii V, et al. Analysis of NHANES 2005-2016 Data Showed Significant Association Between Micro and Macronutrient Intake and Various Sleep Variables Oxford University Press; 2019; 06: 103-19

19.) Baglioni $C$, Nanovska $S$, Regen $W$, et al. Sleep and mental disorders: A meta-analysis of polysomnographic research. Psychol Bull. 2016; 142: 969-90

20.) Berry RB, Brooks R, Gamaldo CE, et al. The AASM Manualfor the Scoring of Sleep and Associated Events. Rules, Terminology and Technical Specifications, Darien, Illinois, American Academy of Sleep Medicine. 2012; 176.

21.) Mollayeva $T$, Thurairajah $P$, Burton $K$, et al. The Pittsburgh sleep quality index as a screening tool for sleep dysfunction in clinical and non-clinical samples: a systematic review and meta-analysis. Sleep Med Rev. 2016; 25: 52-73.

22.) Da Silva AA, De Mello RGB, Schaan CW, et al. Sleep duration and mortality in the elderly: a systematic review with meta-analysis. BMJ Open. 2016; 6: e008119.

23.) Yang $X$, Chen $H$, Li S, et al. Association of sleep duration with the morbidity and mortality of coronary artery disease: a metaanalysis of prospective studies. Heart Lung Circ. 2015; 24: 1180-90.

24.) Qie R, Zhang D, Liu L, et al. Obstructive sleep apnea and risk of type 2 diabetes mellitus: A systematic review and dose-response metaanalysis of cohort studies. Journal of Diabetes. 2020; 12(6): 455-465.

25.) Song SO, He K, Narla RR, et al. Metabolic Consequences of Obstructive Sleep Apnea Especially Pertaining to Diabetes Mellitus and Insulin Sensitivity. Diabetes Metab J. 2019; 43(2): 144-155.

26.) Surani S, Brito V, Surani A, et al. Effect of diabetes mellitus on sleep quality. World J Diabetes. 2015; 6: 868-73.

27.) Cuellar NG, Ratcliffe SJ. A comparison of glycemic control, sleep, fatigue, and depression in type 2 diabetes with and without restless legs syndrome. J Clin Sleep Med. 2008; 4: 50-6.

28.) Faraco G, Iadecola C. Hypertension: a harbinger of stroke and dementia. Hypertension. 2013; 62: 810-7.

29.) Wang Q, Xi B, Liu M, et al. Short sleep duration is associated with hypertension risk among adults: a systematic review and metaanalysis. Hypertens Res. 2012; 35: 1012-8.

30.) Cappuccio FP, Cooper D, D'elia L, et al. Sleep duration predicts cardiovascular outcomes: a systematic review and meta-analysis of prospective studies. Eur Heart J. 2011; 32: 1484-92.

21.) Sherwood A, Hill LK, Blumenthal JA, et al. The effects of ambulatory blood pressure monitoring on sleep quality in men and women with hypertension: dipper vs. nondipper and race differences. Am J Hypertens. 2018; 32: 54-60.

32.) Lo K, Woo B, Wong M, et al. Subjective sleep quality, blood pressure, and hypertension: a meta-analysis. J Clin Hypertens. 2018; 20: 592-605. 33.) Li X, Li J, Liu K, et al. Association between sleep disorders and morning blood pressure in hypertensive patients. Clin Exp Hypertens. 2018; 40: 337-43.

34.) Madsen MT, Huang C, Zangger G, et al. Sleep Disturbances in Patients With Coronary Heart Disease: A Systematic Review. J Clin Sleep Med. 2019; 15: 489-504.

35.) Kim JH, Chang JH, Kim DY, et al. Association Between SelfReported Sleep Duration and Serum Vitamin D Level in Elderly Korean Adults. J Am Geriatr Soc. 2014; 62: 2327-32.

36.) Massa J, Stone KL, Wei EK, et al. Vitamin D and actigraphic sleep outcomes in older community-dwelling men: the MrOS sleep study. Sleep. 2015; 38: 251-7.

37.) Beydoun MA, Ng AE, Kuczmarski MRF, et al. Vitamin D status and its longitudinal association with changes in patterns of sleep among middle-aged urban adults. Journal of Affective Disorders. 2021; 282: 858-868.

38.) Peuhkuri K, Sihvola N, Korpela R. Diet promotes sleep duration and quality. Nutr Res. 2012; 32: 309-19.

39.) Hashimoto S, Kohsaka M, Morita N, et al. Vitamin B12 enhances the phase-response of circadian melatonin rhythm to a single bright light exposure in humans. Neurosci Lett. 1996; 220: 129-32.

40.) Mayer G, Kröger M, Meier-Ewert K. Effects of vitamin B12 on performance and circadian rhythm in normal subjects. Neuropsychopharmacology. 1996; 15: 456-64.

Ankara Eğt. Arş. Hast. Derg. (Med. J. Ankara Tr. Res. Hosp.), 2021 ; 54(3) : 366-371

Necessary permissions were obtained from the Clinical Research Ethics Committee of Bolu Abant Izzet Baysal University to conduct the study. (Approval number: 1012016904, Approval date: 12/09/2019). 